УДК 655.224.261.9:655.366.83

( О. І. Хмілярчук, к.т. н., доцент, А. Д. Шепельова, магістр, КПІ ім. Ігоря Сікорського, Київ, Україна

\title{
АНАЛІТИЧНИЙ ОГЛЯД ТЕХНОЛОГІЙ ПЕРЕНЕСЕННЯ ЗОБРАЖЕННЯ НА ТКАНИНУ
}

\section{У статті представлено аналіз тканин на предмет структури їх волокон, аналіз технологій нанесення зображень на тканину поліграфічними способами; патентний огляд матеріалів і технологій нанесення зображень на тканину за допомогою фольги.}

\section{Ключові слова: перенесення зображення на тканину; властивості тканин; текстильні волокна; друк на тканинах; фольга.}

\section{Постановка проблеми}

Друк на тканині набуває все більшої популярності в галузі моди, дизайну, рекламної індустрії та оформленні інтер'єрів. Завдяки сучасним технологіям така продукція є абсолютно безпечною для здоров'я, тому друкувати можна на спальному текстилі, одязі. Прикладами сфер використання друку на тканині можуть бути оформлення вітрин та місць продажу, виготовлення прапорів, лайтбокси, рекламні банери, декорування інтер'єру, друк декорацій для театрів, друк репродукцій на полотні, сувенірна продукція (футболки, толстовки, кепки тощо), фірмовий одяг для персоналу [1, 2].

Необхідно враховувати, що для різних тканин підходить не кожна технологія перенесення зображення. Для аргументованого вибору технологій нанесення зображень на тканину необхідним $€$ аналіз структури тканини.

\section{Мета роботи}

Розроблення класифікації текстильних волокон та аналіз тканин з точки зору придатності до задруковування поліграфічними способами. Аналіз тенденцій використання фольги для створення зображень на тканині.

\section{Результати проведених досліджень}

Тканина - виріб, виготовлений шляхом переплетення ниток у процесі ткання на ткацькому верстаті. Тканини розрізняють за вихідним матеріалом ниток: шерстяні, шовкові, бавовняні, синтетичні та ін., а також за методом переплетення ниток.

Основним структурним елементом всіх текстильних матеріалів $€$ текстильне волокно. За походженням всі волокна можна поділити на два класи: натуральні та хімічні. Саме такий спосіб поділу (за способом виготовлення волокон) та їх хімічний склад

(c) $2017 \mathrm{p}$ 
покладені в основу класифікації текстильних волокон, що представлена на рис. 1.

Натуральні волокна існують в природі, а хімічні виготовляються в умовах промислового виробництва. До натуральних відносяться волокна рослинного (бавовна, льон, пенька, джут та інші), тваринного (вовна та натуральний шовк) та мінерального (азбест) походження, які утворюються в природі без участі людини. Натуральні рослинні волокна складаються з природної ВМС-целюлози. Їх отримують з поверхні насіння рослин (бавовна), зі стеблин (льон, джут, конопля, кенаф), з листя (абака - текстильний банан, сизаль). Натуральні волокна тваринного походження складаються з білків: кератину (вовна) або фіброїну (натуральний шовк).

До хімічних відносяться волокна, які створюються у виробничих умовах методом їх формування з природних або синтезованих полімерів (високомолекулярних сполук) [3]. За хімічним складом всі волокна, крім мінеральних, представляють собою органічні речовини - це різні природні та здобуті хімічним способом високомолекулярні сполуки (ВМС).

Органічні хімічні волокна поділяються на штучні та синтетичні.

Штучні волокна здобувають методом промислової переробки природних полімерів. Основні види штучних волокон: віскоза, полінозне, віскозне високомодульне волокно сіблон, ацетатне та триацетатне.

Синтетичні волокна здобувають $з$ синтезованих полімерів.
Основні види синтетичних волокон: капрон, анід, лавсан, нітрон, вінол, хлорин, спандекс.

Також дуже важливими є фізичні властивості тканини, а саме термостійкість, оскільки під час використання ряду технологій процес буде супроводжуватись досить високою температурою. Підвищена температура може викликати або різке руйнування тканини внаслідок розплавлення (з гетероланцюгових синтетичних і ацетатних волокон), або поступове її руйнування (виникнення жорсткості, погіршення інших механічних властивостей).

Лляні, бавовняні тканини і тканини з віскозного штапельного волокна можна піддавати обробці температурою не вище $300^{\circ} \mathrm{C}$, вовняні та напіввовняні тканини 220-250 C, при цьому час впливу температури на тканину не має перевищувати 120-125 с. При впливі на вовняні тканини, що містять капрон, температура не повинна бути вище $140-160^{\circ} \mathrm{C}$, а тканин, що містять лавсан $140-180^{\circ} \mathrm{C}$, тканини 3 ацетатного волокна - 80 C [3-5].

Згідно з проведеним аналітичним дослідженням, на сьогодні існує велика кількість способів нанесення зображення на тканину. Умовно їх можна поділити на декоративні (вишивка, ручний розпис) та поліграфічні (сублімаційний друк, термоперенесення, трафаретний друк, нанесення фольги на тканину, друк флекс плівками, прямий друк на тканинах).

Сублімаційний друк - друк, при якому фарба при температурі $180-200^{\circ}$ C і під дією тиску переходить з проміжного носія 


\section{Т ЕХНОЛОГ І Ч Н П П РО ЦЕ С И}

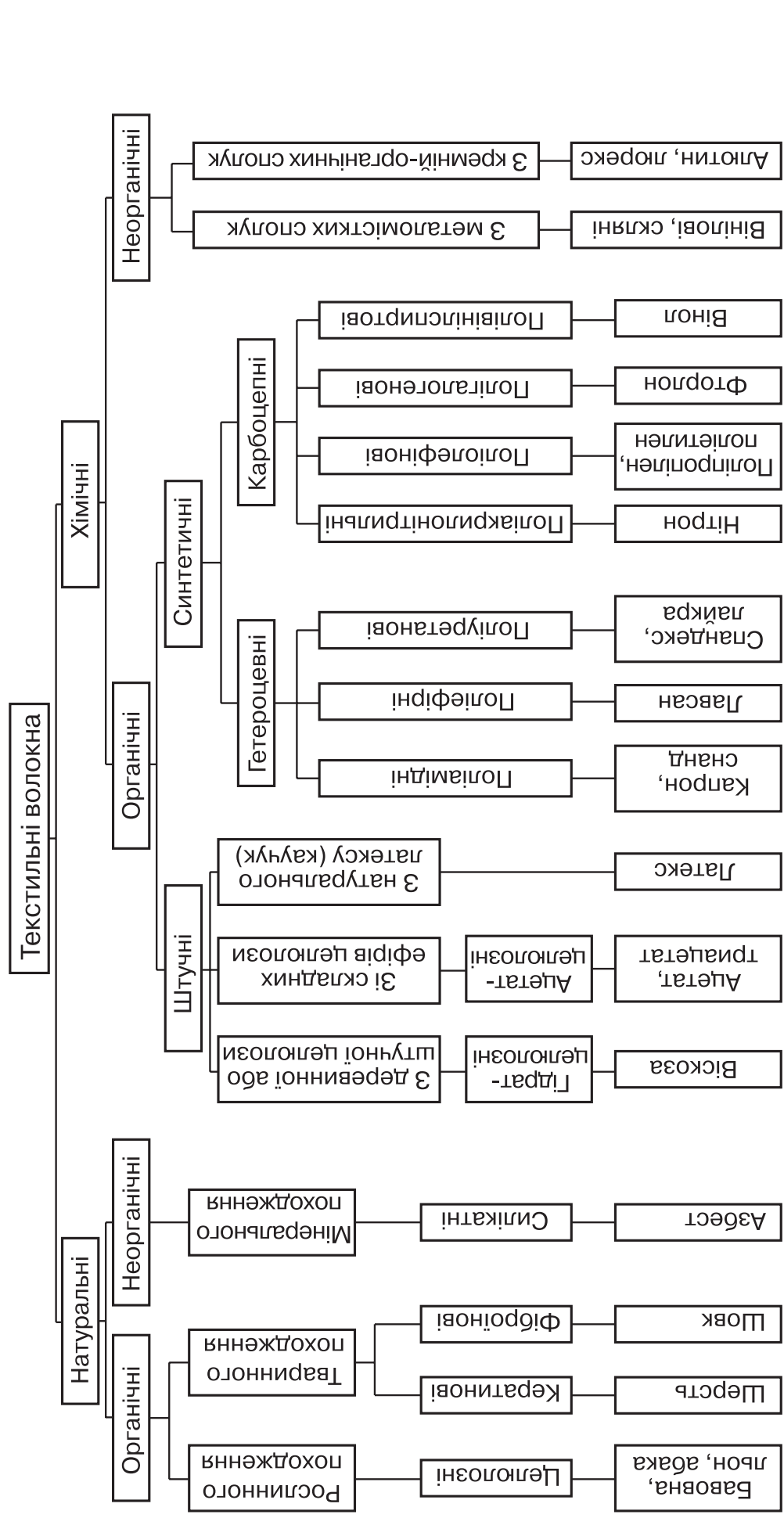

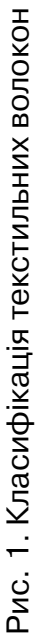

$\widehat{5}$

든

인

r.

임

I

চே

ำ

음

즐

음

ช్

产

(1)

-

뜨

능

은

ำ

I

$\dot{8}$

ڤ్

N

N

今

ก

B

(D) 
на поверхню, що задруковується. Для цієї технології використовуються спеціальні барвники, які після отвердіння на проміжному носії являють собою речовину для сублімації. Для якісного переносу зображення на матеріал необхідний повний контакт між проміжним носієм та задрукованою поверхнею, рівномірний розподіл температури. Як задрукований матеріал використовується дерево, метал, скло, пластик та тканина з попередньою підготовкою поверхні.

Основним недоліком сублімаційного друку є закріплення барвників лише на полімерних матеріалах. Тканина повинна містити не менше 65 \% синтетичного волокна у складі. Для перенесення зображення на інші задруковувані поверхні використовується спеціальний покривний лак на основі акрилополіуританових композицій. До основних переваг сублімаційного друку на тканинах відносять «еластичність зображення» фарбовий шар не тріскається при розтягненні, висока стійкість до процесу прання [1].

Термоперенесення (термотрансфер) - технологія нанесення зображення на тканину зі спеціального, попередньо задрукованого паперу за допомогою термопресу. Термотрансферний папір - папір з нанесеною прозорою плівкою, на яку наноситься зображення за допомогою лазерного або струминного принтера. Основними технологічними факторами процесу $€$ : температура плити термопресу, тиск та час переносу зображення. Для даної технології час варіюється від 5 до 30 секунд, а температура лежить в межах 120-190 C.

Переваги технології: перенесення точних штрихових елементів, фотографічна якість перенесеного зображення, економічність при друці одиничних тиражів. Основним недоліком $€$ погана стійкість зображення до прання.

Друк флекс плівками - нанесення зображення за допомогою спеціальних різнокольорових плівок. Зображення, що наноситься, вирізається з одноколірної плівки на ріжучому плоттері i припресовується до тканини за допомогою термопресу. Створене зображення не виводиться пранням і не вицвітає, але нестійке до дії агресивного середовища (наприклад розчиняється у спирті). Флекс плівками неможливо відтворити півтонове зображення, технологія призначена для нанесення векторних сюжетів, наприклад, тексту або нескладних логотипів. Оптимальним є використання не більше трьох різних плівок, оскільки виникають проблеми з суміщенням зображення. Ще одне обмеження технології дрібні деталі. Деякі елементи дизайну просто неможливо вирізати, для складних елементів зображення обмеження становить більше 1 мм.

Трафаретний друк - спосіб друку, при якому зображення отримується шляхом продавлювання фарби через трафаретне сито. Як формний матеріал використовуються спеціальні поліефірні, поліамідні (нейлонові) 
моноволокна або металеві сітки частотою 4-400 ниток/см і товщиною приблизно 40-500 мкм.

Однією з особливостей трафаретного друку $€$ можливість отримувати товстий фарбовий шар від 8-10 мкм до 1000 мкм, з високою покриваністю і яскравістю кольору. Також можна широко використовувати ефекти: гліттер, об'ємний друк, імітацію оксамиту або гуми. До недоліків трафаретного друку в першу чергу слід віднести високу собівартість при одиничних тиражах.

Прямий друк на тканині спосіб нанесення зображення на тканину, що передбачає прямий друк без проміжних носіїв. Перенесення зображення подібне звичайному друку на папері або інших стандартних носіях, але вимагає принципово іншого друкарського блоку і фарб на основі оксидів металів, здатних надійно утримуватися на тканині. При використанні такої технології необхідна підготовка матеріалу: пригладжування ворсу та постпроцес обробки виробу фіксація нагріванням (до $150^{\circ} \mathrm{C}$ ). Для прямого друку можуть використовуватися як спеціалізовані пристрої, так і широкоформатні струминні принтери зі спеціальним блоком сопел.

Переваги прямого друку на тканині: оптична роздільна здатність до 1440 dрі (Фактично залежить від текстури тканини); рівень деталізації набагато вище, ніж при термотрансферному чи трафаретному друці; технологія має всі переваги цифрової поліграфії: низька собівартість при малих тиражах, швидкість, гнучкість зміни макета; зображення витримує біль- ше 60 циклів прання без істотної втрати якості, так як полімеризовані фарби всотуються в структуру тканини; доступні ефекти, зокрема, глянець і плавні градієнти.

Нанесення фольги на тканину - технологія нанесення металізованої фольги на текстильні вироби та елементи крою об'єднує в собі нанесення клейового шару з подальшим перенесенням на нього фольги в трансферному пресі. Основними перевагами даної технології $€$ висока стійкість фольги до вицвітання та механічної дії. До суттєвих недоліків можна віднести трудомісткість процесу та неможливість відтворення півтонових зображень. Окрім того існує проблема приведення, тому рекомендується використання не більше ніж двох видів фольги. Але у результаті є можливість створити на виробі яскраве металізоване зображення $[2,6]$.

У таблиці наведено порівняння технологій перенесення зображення на тканину.

Технологія нанесення металізованої фольги на текстильні вироби є однією 3 найменш досліджених. Тому було проведено патентний пошук за технологіями, матеріалами та обладнанням 3 перенесення фольги на задруковуваний матеріал. Згідно патентного пошуку за період 1995-2014 рр., знайдено близько 100 патентів, що відповідають заданій тематиці (рис. 2). Обмеження пошуку 20 роками пояснюється тим, що більшість ідей, опублікованих до визначеного періоду, є дещо застарілими на сьогодні. Географія 


\begin{tabular}{|c|c|c|c|c|c|c|c|}
\hline 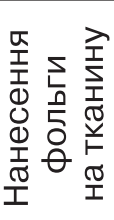 & 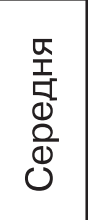 & & 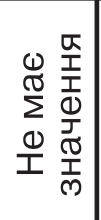 & 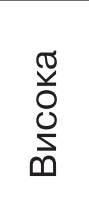 & 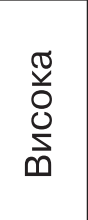 & 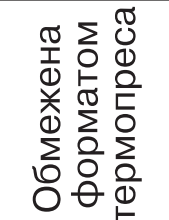 & \\
\hline 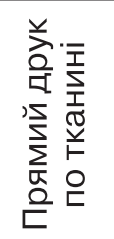 & 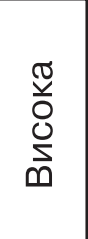 & + & 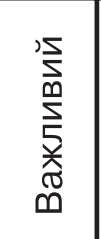 & $\begin{array}{l}\text { ত } \\
\text { o } \\
0 \\
\stackrel{\square}{0}\end{array}$ & 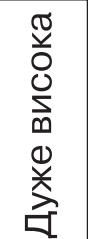 & 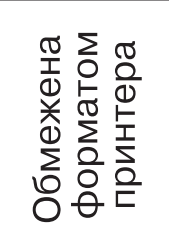 & + \\
\hline 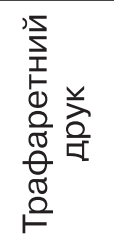 & 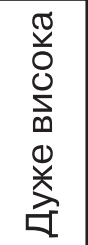 & $\mid$ & 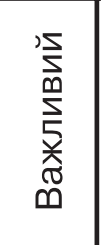 & $\begin{array}{l}\text { v } \\
\text { o } \\
0 \\
\text { ஸे }\end{array}$ & 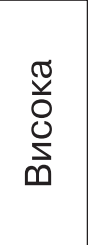 & 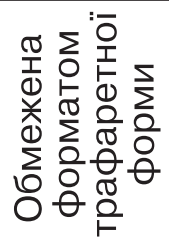 & 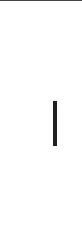 \\
\hline 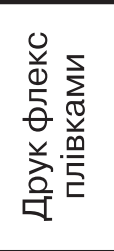 & 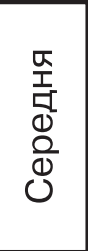 & $\mid$ & 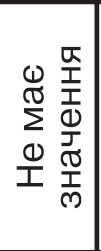 & 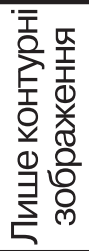 & 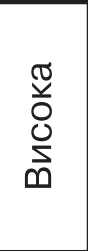 & 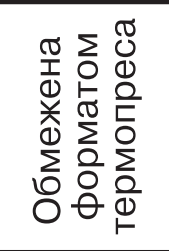 & \\
\hline 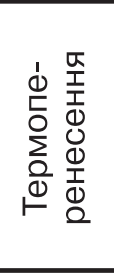 & $\begin{array}{l}\text { 똠 } \\
\text { 덩 } \\
0 \\
000 \\
0 \\
0\end{array}$ & + & 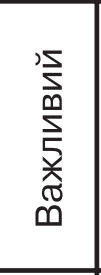 & 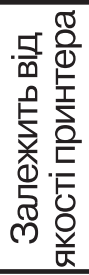 & 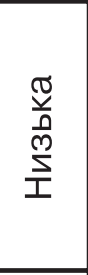 & 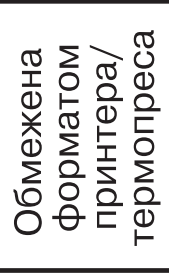 & + \\
\hline 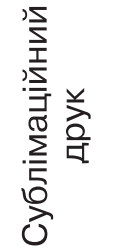 & 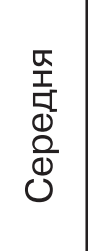 & + & 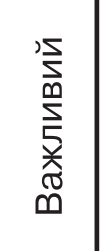 & 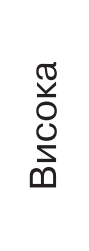 & 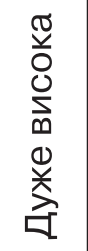 & 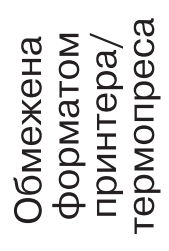 & + \\
\hline $\begin{array}{l}\stackrel{2}{E} \\
\sum_{\mathbb{0}}^{0} \\
\frac{2}{\sigma} \\
\frac{0}{C}\end{array}$ & 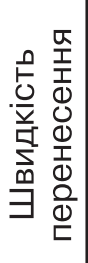 & 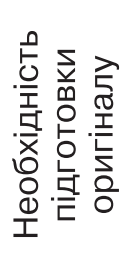 & 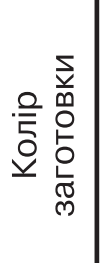 & 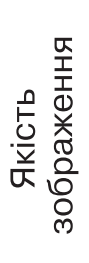 & 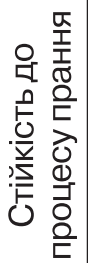 & 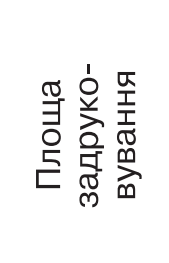 & 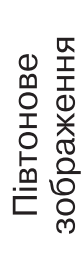 \\
\hline
\end{tabular}




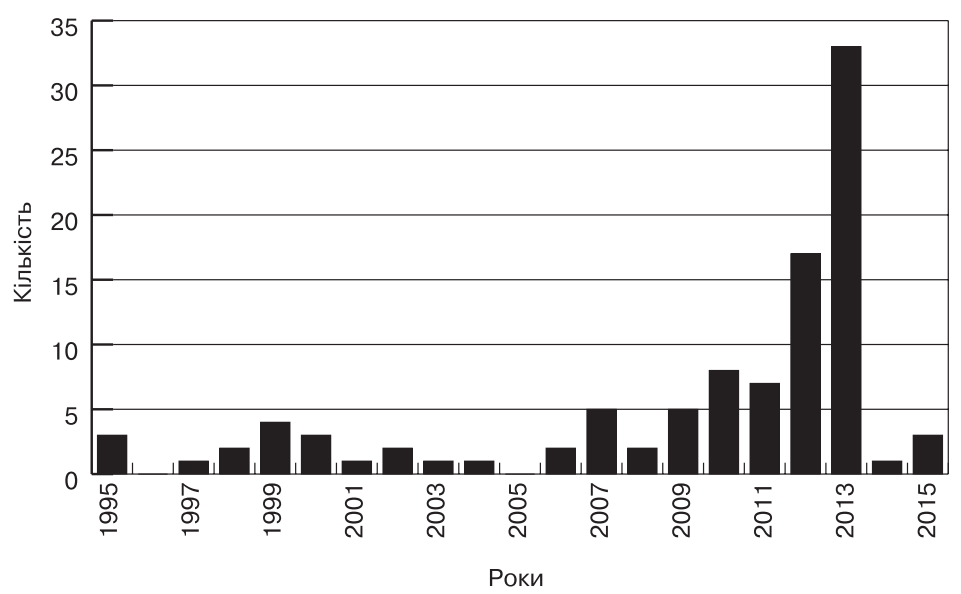

Рис. 2. Динаміка патентування технологій нанесення металізованої фольги на текстильні вироби

вибірки максимально широка: Україна, США, РФ, Корея, Японія, Франція, Німеччина, Великобританія.

Як джерела пошуку використано: Федеральна служба з інтелектуальної власності, патентів та товарних знаків (ФГУ ФИПС), Europian Patent Office (Esp@cenet), Всесвітня організація інтелектуальної власності (WIPO), Євразійська патентно-інформаційна система (EAPATIS), Державне підприємство «Український інститут промислової власності» (УкрПатент), United States Patent and Trademark Office (USPTO), Abstract of Japan.

Міжнародний клас патентів переважно B44C, B42C, B32.
На рис. 3 представлено розподіл патентів за матеріалами, для яких розроблено технології тиснення фольгою. Найбільшу нішу займає папір та картон $32 \%$, на тиснення по тканинах припадає 14 \%, при чому, що всі патенти були опубліковані у 2012-2013 рр., що свідчить про актуальність даної технології. На рис. 4 представлено розподіл патентів за фірмами-правовласниками.

\section{Висновки}

Розроблено класифікацію тканин за походженням волокон, що дало змогу в подальшому аргументувати вибір зразків для проведення досліджень.

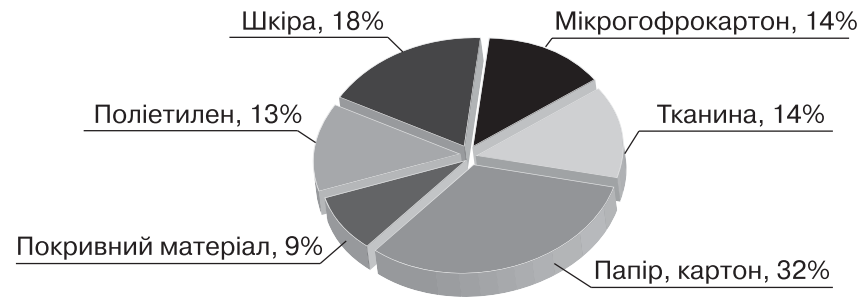

Рис. 3. Розподіл патентів за матеріалами для тиснення фольгою 


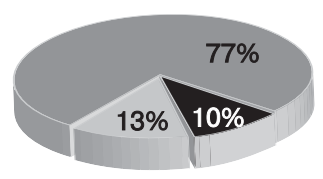

Shanghai tnme printing material co LTD (KHP)

$\square$ Kurz (Німеччина)

Yunnan yuxi Dongmei packeging materials co LTD (Японія)

Рис. 4. Розподіл патентів за фірмами правовласниками

Зроблено порівняльний аналіз існуючих технологій нанесення зображення на тканину, зокрема процес перенесення фольги.
Проведено патентний пошук за технологіями, матеріалами та обладнанням з перенесення фольги на задрукований матеріал, що підтвердили актуальність дослідження.

\section{Список використаної літератури}

1. Узоры на ткани : эффектно, ярко, необычно. Современные возможности печати // Формат - 2008. - № 3. - Режим доступу : http://www.kursiv.ru/kursivnew/format_magazine/archive/35/4.php\#text.

2. Хмілярчук О. І. Оцінка якості гарячого тиснення фольгою на шкірі та замінниках шкіри / О. І. Хмілярчук, К. О. Чепурна, Ю.В.Екгардт // Технологія і техніка друкарства. - 2012. - № 3(37). - С. 87-96. - Режим доступу : http://ttdruk.vpi.kpi.ua/article/view/32403.

3. Москалев В. М. Текстильные материалы, применяемые в химической промышленности / В. М. Москалев [Текст]. - М. : Типо-графия Госхимиздат, 1954. - $117 \mathrm{c.}$

4. Бузов Б. А. Материаловедение швейного производства / Б. А. Бузов, Т. А. Модестов, Н. Д. Алыменкова [Текст]: 4-е изд., перераб. и доп. - М. : Промиздат, 1986. - 424 с.

5. Ganguly D. Foil Printing on Textile Material / D. Ganguly // Man-made Textiles in India - 2012. - \# 2. - pp. 51-55.

6. Гилязетдинов Л. П. Фольга для горячего тиснения / Л. П. Гилязетдинов, Г. М. Левин, М. В. Огороднева [Текст]. - М. : Книга, 1981. - 114 с.

\section{References}

1. (2008). Uzory na tkani: jeffektno, jarko, neobychno. Sovremennye vozmozhnosti pechati [Patterns on the fabric: effective, bright, unusual. Modern printing capabilities]. Journal of Format, 3. Retrieved from http://www.kursiv.ru/ kursivnew/format magazine/archive/35/4.php\#text [in Russian].

2. Khmiliarchuk, O. I. \& Chepurna, K. O. \& Ekhardt, Iu. V. (2012). Otsinka yakosti hariachoho tysnennia folhoiu na shkiri ta zaminnykakh shkiry [Assessment of quality of hot stamping foil for leather and leather substitutes]. Journal of Tekhnolohiia i tekhnika drukarstva - Technology and Technique of Typography, 3(37), 87-96. Retrieved from http://ttdruk.vpi.kpi.ua/article/view/32403 [in Ukrainian].

3. Moskalev, V. M. (1954). Tekstil'nye materialy, primenjaemye v himicheskoj promyshlennosti [Textile materials used in the chemical industry]. Moscow: Tipografija Goshimizdat [in Russian].

4. Buzov, B. A. \& Modestov, T. A. \& Alymenkova, N. D. (1986). Materialovedenie shvejnogo proizvodstva [Material science of clothing manufacture]. Moscow: Promizdat [in Russian].

5. Ganguly, D. (2012). Foil Printing on Textile Material. Journal of Man-made Textiles in India, 2, 51-55 [in English]. 
6. Giljazetdinov, L. P. \& Levin, G. M. \& Ogorodneva, M. V. (1981). Fol'ga dlja gorjachego tisnenija [Foil for hot stamping]. Moscow: Kniga [in Russian].

В статье представлен анализ тканей на предмет структуры волокон, анализ технологий нанесения изображения на ткань полиграфическими способами; патентные исследования материалов и технологий нанесения изображений на ткань с помощью фольги.

Ключевые слова: перенос изображения на ткань; свойства тканей; текстильные волокна; печать на тканях; фольга.

The article presents the analysis of tissue structure in terms of fiber technology, image transfer on fabric by printing method; patent research materials and technologies for creating images on fabric using foil.

Keywords: image transfer on fabric; properties of fabrics; textile fibers; printing on fabrics; foil.

\author{
Рецензент - О. І. Лотоцька, к.т.н., доцент, \\ КП। ім. Ігоря сікорського
}

Надійшла до редакції 13.01.17 